10. Royik O. V. Elektronne sudochynstvo. Chy maye Ukrayina shansy? [Electronic Judiciary. Does Ukraine have any chance] URL: http://yur-gazeta.com/dumka-eksperta/elektronne-sudochinstvochi-mae-ukrayina-shansi.html. [in Ukr.]

11. Shchodo Polozhennya pro avtomatyzovanu systemu dokumentoobihu sudu [Concerning the Regulation on the automated system of court circulation]: Rishennya Rady suddiv Ukrayiny vid 26 lystopada 2010 r. № 30. Visnyk Verkhovnoho Sudu Ukrayiny. 2010. № 51. S. 5. [in Ukr.]

12. Yudin, O. K., Bohush, V. M. (2005) Informatsiyna bezpeka derzhavy [Information Security of the State]: navch. posibnyk. Kharkiv: Konsum,. 576 s. [in Ukr.]

\title{
Summary
}

The article is devoted to the analysis of scientific concepts and the legal framework of the concept of information support for administrative legal proceedings. Features and peculiarities of information provision for administrative legal proceedings are studied; its differences from information support for the administrative court are stressed. The author's definitions of the concept of information support for the administrative procedure and information support for the administrative court are proposed. Three stages of formation of national legislation regulating information provision of administrative legal proceedings are singled out. The system of laws and regulations, which provisions consolidate legal fundamentals of information support for administrative legal proceedings, is clarified. Prospective directions for the development of scientific inquiry in the field of information support for administrative legal proceedings and its legal regulation are revealed.

The conditional stages of the formation of the legal regulation of the information provision of administrative legal proceedings determined by us were based on events of key importance for the formation of the information support system of administrative legal proceedings and were accompanied by secondary fragmentary changes that concerned only information provision of certain types of administrative cases.

Keywords: administrative jurisdiction, administrative legal proceedings concept, administrative procedure, courts rules, subject.

UDC 342.95

DOI: $10.31733 / 2078-3566-2019-5-84-90$

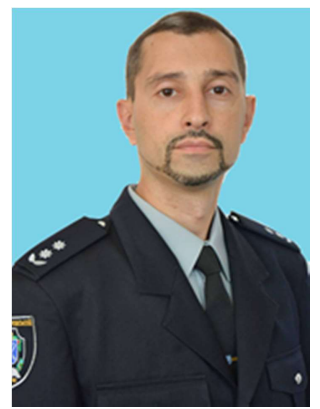

Andriy

SOBAKAR ${ }^{\circ}$

Dr of Law, Prof.
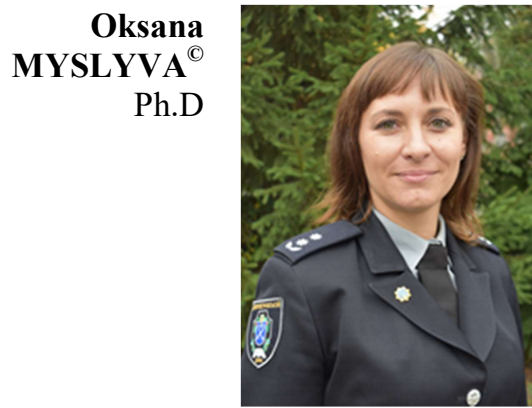

(Dnipropetrovsk State University of Internal Affairs)

\section{MEASURES TO ENSURE PROCEEDINGS IN ADMINISTRATIVE OFFENSES THAT RESTRICT PROPERTY RIGHTS}

Андрій Собакарь, Оксана Мислива. ЗАХОДИ ЗАБЕЗПЕЧЕННЯ ПРОВАДЖЕННЯ У СПРАВАХ ПРО АДМІНІСТРАТИВНІ ПРАВОПОРУШЕННЯ, ЩО ОБМЕЖУЮТЬ НЕМАЙНОВІ ПРАВА. В Україні передбачено чимало адміністративно-правових інструментів охорони правопорядку, захисту прав та інтересів громадян, в переліку яких особливе місце займають заходи забезпечення провадження у справах про адміністративні правопорушення. Їх застосування реалізує припинення адміністративних проступків, встановлення особи порушника, складання протоколу про адміністративне правопорушення, забезпечення своєчасного і правильного розгляду справи, забезпечення виконання постанов у справах про адміністративні правопорушення, документування факт доказів його вчинення. Останнім часом законодавство зазнало суттєвих змін у

(C) Sobakar A., 2019

ORCID iD: https://orcid.org/0000-0002-7618-0031

aasobakar77@ukr.net

(C) Myslyva O., 2019

ORCID iD: https://orcid.org/0000-0002-0181-9603

omaxah@gmail.com 
зв'язку з реформуванням правоохоронних органів і судової системи. Отже, удосконалення законодавства 3 указаних питань буде сприяти створенню передумов формування надійних засобів захисту прав і свобод людини і громадянина, інтересів суспільства і держави, підвищенню ефективності адміністративно-правового впливу.

Отже, у статті проаналізовано нормативні джерела регламентації заходів забезпечення провадження за класифікацією, яка включає три групи заходів забезпечення провадження у справах про адміністративні правопорушення за правовою природою обмеження конституційних прав особи у зв'язку із застосуванням до неї примусових заходів за вчинене правопорушення: майнових, немайнових і комбінованих. 3 них до немайнових саме і належать заходи забезпечення провадження у справах про адміністративні правопорушення, що обмежують немайнові права: право на свободу пересування та особисту недоторканність тощо. Наголошується, що норми КУпАП про адміністративне затримання (ст. 261-263), доставлення (ст. 259) та привод (ст. 268) особи іє тими засобами забезпечення провадження у справах про адміністративні правопорушення, які обмежують її свободу пересування.

На підставі відмежування понять правових режимів «затримання», «арешту», «ув'язнення», «обмеження пересування особи» та «утримання особи в спеціально відведених для цього приміщеннях», обгрунтовується потреба законодавчого закріплення поняття «момент (фактичного) затримання», початком якого пропонується вважати момент фактичного обмеження свободи пересування шляхом психологічного впливу на свідомість особи правопорушника (усний наказ) або шляхом вчинення конклюдентних дій (тактильний контакт: фізична сила, кайданки та інші заходи, передбачені чинним законодавством).

У статті обгрунтовується потреба удосконалення поняття «адміністративний привод» та його змісту, адже системний аналіз законодавства щодо заходів забезпечення провадження майнового характеру дав можливість виявити невідповідність назви та змісту ст. 268 КУПАП, оскільки привод особи та їі обов'язок з'явитися до суду не мають нічого спільного з правами учасника провадження.

Ключові слова: адміністративне правопорушення, провадження у справах, обмеження, немайнові права

Problem statement. Among the wide arsenal of administrative and legal instruments of strengthening in the society of law and discipline, protection of law and order, protection of rights and interests of citizens, creation of normal conditions for the activity of the apparatus of public power occupy a special place measures to ensure proceedings in cases of administrative offenses. Their application is of double importance: first, they are used to stop administrative misconduct when other measures of influence have been exhausted, to identify the offender, to draw up a report on an administrative offense, to ensure timely and correct consideration of the case, to resolve it in exact accordance with the law, to ensure execution of decisions in cases of administrative offenses, etc.; secondly, they are regarded as fixing not only the fact of the offense but also the evidence of its commission.

Characteristic features of administrative enforcement proceedings are that they are independent, and thus are ancillary to influence, are not considered sanctions and do not impose additional restrictions on the offender. However, the current legislation, in particular. Code of Ukraine on Administrative Offenses (hereinafter referred to as the CUAO) [1], although the procedural procedure for their application (list of authorized bodies and officials having jurisdiction, terms, procedural procedure, procedure for appeal), definition of substance, content, grounds, grounds, procedures and features of their application is of great importance both theoretical and practical.

Most of the national scientific works on the studied issues have significant achievements, however, they are somewhat outdated. Emphasis should be placed on the numerous reforms introduced in Ukraine. Thus, the insufficiency of theoretical developments and the existence of practical legal problems in the application of measures to ensure proceedings in administrative offenses led to the choice of the topic of the dissertation. Improvement of legislation on these issues will help to create the preconditions for streamlining the activities of administrative jurisdictions, the formation of reliable means of protection of human and citizen's rights and freedoms, the interests of society and the state, strengthening the rule of law, increasing the effectiveness of administrative and legal influence.

The article's objective is to determine, on the basis of the analysis of the current legislation and the general practice of its application, the theoretical basis, the legal nature and the peculiarities of the application of measures for the maintenance of administrative offenses in cases of administrative offenses and on that basis to develop proposals for their improvement.

Basic content. Administrative detention (Art. 261-263 of the CUAO), delivery (Article 259 of the CUAO es) and the occasion (Article 268 of the CUAO) are the means of ensuring proceedings in administrative offenses which restrict its freedom of movement. The measures 
under consideration are the same in nature, as they restrict the freedom of movement of the offender and should therefore constitute a single system of measures and be contained in Chapter 20 of the CUAO.

The general principles of their application are provided by the const. 29 and 59 of the Constitution of Ukraine, General Assembly Resolution 43/173 of December 9, 1988 "A set of principles for the protection of all persons subject to detention or imprisonment in any form" [2], Art. 37 of the Law of Ukraine "On the National Police" and other laws and by-laws.

Yes, in Art. 29 of the Constitution of Ukraine, every person is guaranteed the right to liberty and security of person, which is that no person can be arrested (or remanded in custody) except by reasoned court decision and only on the grounds and in accordance with the procedure established by law. According to Art. 59 of the Constitution of Ukraine, every detainee has the right to use the assistance of a lawyer (defender) from the moment of detention [3]. In each case of administrative detention, the authorized person is obliged to immediately notify the center for the provision of free secondary legal assistance by telephone or other communications [4]. Refusal of the defender can only occur after the lawyer has arrived at the specified premises and has received it himself in the form of a written application, a copy of which he submits to the respective regional center.

The principle of protection of all persons subject to detention or imprisonment in any form emphasizes that protection is required of every person "who is detained in any form" [2]. This international act defines the concept and legal regime of "detention", "arrest" and "imprisonment". The term "detention" should be understood as such a person's condition if he or she is deprived of his personal liberty "not as a result of a conviction for an offense". The term "imprisonment" includes conviction when a person is deprived of his personal liberty for committing any offense, and "arrest" is the act of detaining a person on suspicion of committing any offense or at the discretion of a specific authority. According to the rules of formal logic, the terms "arrest" and "detention" in international documents are used in connection with the procedure of prosecution for committing a crime, and "detention" for offenses (misdemeanors). This is borne out by the content of Principle 8 of the Code, which requires detainees to be held in non-convicted status and kept separate from prisoners.

The Code of Conduct regulates relations in this area, although unlike the previous normative act, it does not provide any definition of delivery, administrative detention and reason. In determining their content, it is advisable to refer to their scientific and logical interpretation.

The term "detention" is used in Art. 37 of the Law of Ukraine "On the National Police" in connection with the application to the person of such preventive police measure as "restriction of movement of the person", and "on the grounds, in the order and for the terms determined by ... Code of Ukraine on Administrative Offenses, as well as other laws Of Ukraine "(part 1) [5]. Also restriction of movement of a person in accordance with Part 2 of Art. 37 of the that Law may take the form of "detention of a person in specially designated premises", the countdown of which begins from the moment of actual detention.

In addition, the procedure and grounds for detention and detention of a foreigner or stateless person in a temporary detention facility to secure forced expulsion outside Ukraine is provided for by the Law of Ukraine "On the Legal Status of Aliens and Stateless Persons" [6].

The term "detention of persons in detention rooms" is used by the legislator in the Instruction on Organizing the Activity of the Service of Bodies (Units) of the National Police of Ukraine (paragraph 6 of Part 7 of Section I), which essentially includes not only restriction of the freedom of movement of a person in within certain premises, as well as organization of work with detainees (filing commands, use / removal of handcuffs, etc.), ensuring their constitutional rights and freedoms, etc. (food, water, toilet, notification of location) [7].

The current legislation lacks a common understanding of the moment when the detention period begins to be calculated. The concept of "moment of actual detention" (Article 115 and Article 186) and "Actual detention" (Article 209) are contained in the CPC of Ukraine. Thus, Art. 209 of the CPC of Ukraine defines the moment of detention: "A person is detained from the moment when by force or by subjugation of an order he is forced to stay near an authorized officer or in a premises designated by an authorized official" [8]. At the same time, in Part 4. Art. 507 of the Criminal Code of Ukraine "the term of administrative detention shall be calculated from the moment of delivery of the person to the official premises of the body of revenue and fees or to other premises..." [9]. Articles 260-263 of the CUAO do not contain information on the beginning and the end of detention. Administrative detention is a form of restriction of movement of a person of the kind which is to keep him in a specially designated room, which 
starts from the moment when he is obliged by force or by subjugation to remain near an authorized officer or in a place designated by an authorized officer on the premises on the grounds, in the manner and for the terms, determined by the CUAO and other laws of Ukraine, and shall be terminated at the moment when the detained person is handed a copy of tokolu or decision of the offense and in case of refusal to receive it - the signing of these documents witnesses.

As previously emphasized, the notion of "detention" in current legislation and international norms applies not only to an individual, but also to things. Thus, in Part 4 of Art. 36 of the Air Code of Ukraine contains the concept of "aircraft detention", which is used as a fiscal security measure [23].

A number of scientists propose that under the delivery of the offender as a measure of enforcement proceedings to consider a coercive measure that restricts the freedom of action and movement of the person, affecting his honor and dignity, because "delivery of the offender is not only the forced escort of the person to law enforcement, but also the implementation of the law provided to personal freedom of the person in the interests of law enforcement » [66, p. 195-196]. There is a reasonable view that delivery is a preliminary stage of administrative detention $[10,162]$.

The individual normative regulation of each of the investigated procedures testifies to their certain independence. They should be considered within the framework of a single procedural model, because they are interconnected and interconnected in terms of content and legal status. Delivery law uses the term "stay" of the delivered person in the listed service premises. Administrative detention also implies a similar "offender" stay, but with compulsory drafting of the relevant Protocol, while only the authorized person's report is made on delivery. In our view, this creates confusion in delimiting activities that restrict one's personal freedom.

The possibility of delivering a person who has committed an offense not authorized by that person is allowed not by administrative but by the criminal procedural legislation in the order of Part 2 of Art. 207 of the CPC of Ukraine "Legal detention" [99].

Analysis of the above list of persons in Art. 262 of the CAO of Ukraine states that not all administratively authorized officials are given the same powers of administrative detention, which emphasizes the relative autonomy of both measures. It is also worth noting that the Code of Conduct in the studied norm and now unjustifiably operates with outdated terminology "law enforcement agencies", which needs to be eliminated from the very beginning of the reform of the law enforcement system.

The list provided in Art. 262 of the Administrative Code of Officials is exhaustive because the detention of a person against his will is indoors (room, chamber, cellar, etc.) or in a complex of premises (basement of a multi-storey building, a hospital), and in other places (the roof of a multi-storey building, vehicle) by a person who is not empowered with special powers constitutes a crime under Art. 146 of the Criminal Code of Ukraine "Unlawful imprisonment or kidnapping" [106].

The term "drive" is found in the Criminal Procedural Code of Ukraine only in Art. 268. According to Part 2 of Art. 268 of the Administrative Code in the consideration of cases of administrative offenses, provided for in Part 1 of Art. 44, Art. 51, 146, 160, 172-4 - 172-9, 173, 173-2, Part 3 of Art. 178, Art. 185, 185-1, Art. 185-7, 187 of this Code, the presence of a person held administratively liable is obligatory. Therefore, in the event of evasio- of a summon by police or a judge of a district, district, city, city or district court, this person may be subject to reason by the National Police. At the same time in Part 3 of Art. 268 of the CAO of Ukraine states that the laws of Ukraine may provide for other cases where the appearance of a person held to administrative liability is compulsory.

Among the rules of current law, the concept of the drive provides only part 1 of Art. 140 of the Criminal Procedural Code of Ukraine "Drive": "The drive consists in the compulsory escort of the person to whom it is applied, by the person executing the decision to carry out the drive, to the place of its call at the time specified in the order" [8]. The grounds and conditions of the case for the purpose of ensuring the presence of the person who committed the offense and whose personal participation is considered compulsory by the court, are determined in Art. 272 "Drive" of the Code of Administrative Judiciary of Ukraine (hereinafter CAJU) [11]. The reason for the use of the actuator is a court order stating the personal information of the individual, place of residence (stay), work, service or training, reasons for the use of the actuator, the subject of execution, time and place of delivery.

Art. 272 of the CAJU provides that the case is brought to court by the bodies of the Na- 
tional Police (according to the wording of the rule, the outdated term "law enforcement agencies" is used, which must be corrected by the legislator). In practice, the decision to drive is transmitted for execution to the territorial police department at the place of proceedings or at the place of residence (stay), work, service or training of the person to be brought.

A special feature of the drive is the special subject of execution: a police officer. The enforcement of a case in enforcement proceedings is one of its main areas of activity in paragraph 11 of Part 2 of Section II of the Instruction on the Organization of the Activities of Police Officers of the Police (paragraph 12 of Part 3 of Section II). The district police officers interviewed by us believe that the involvement of district police officers in the occasions should be optional because the prevention sector is not operationally operational and there are criminal police units. In addition, stated in Art. 272 CAJU 's guarantee of reimbursement to the state of the expenses for the operation of the occasion does not have in practice a mechanism of implementation, which is why police officers often carry it out at their own expense. This negatively affects the quality of their work and promotes abuse.

In view of the above, we propose to provide in a separate rule of the Administrative Institution Administrative Instruction as an independent version of measures to ensure proceedings in cases of administrative offenses in a blanket standard and to state in the following wording: «On the implementation of the case, to the place of her summoning at the time specified in the order, in order to ensure her presence in the consideration of administrative offenses envisaged ... tattyamy this Code.. The enforcement of the decree on the implementation of the case may be entrusted to the relevant units of the National Police... The administrative act shall be subject to the requirements of Art. 272 of the Code of Administrative Judiciary of Ukraine... In case of non-fulfillment by the person subject to the law of the legal requirements for the execution of the decree on the exercise of the case, the measures of physical influence may be applied to it, in the manner and in compliance with the requirements stipulated by the legislation of Ukraine».

At present, the national legislation provides for several concepts that form a single institute of personal inspection: "superficial inspection" (Article 34 of the Law on the National Police), "personal inspection and review of things" (Article 264 of the Administrative Code and Article 340 of the CC of Ukraine), "Personal search" (Part 8 of Article 191, Part 6 of Article 208 of the CPC of Ukraine), "Person Search" (Part 3 of Article 208, Part 5 of Article 236 of the CPC). We distinguish the concept of personal inspection and review of things provided for in Art. 264 of the Code of Administrative Offenses from similar procedures.

Thus, in the Law of Ukraine "On National Police" among preventive police measures the legislator provided for a surface check, which is carried out by visual inspection of a person, conducting on the surface of a person's clothing with a hand, a special device or a means, a visual inspection of a thing or a vehicle [5]. This notion became the successor to the notion of "external review", previously existing in the Statute of the Patrol and Police Service, but has changed substantially in content and legal status, since it is now enshrined in the norm of the Law and not a by-law.

The legislator does not provide definitions of personal inspection either in the CUAO or in the Customs Code of Ukraine. At the same time, in Art. 304 of the Criminal Code of Ukraine personal examination is determined by an exclusive form of customs control, which is carried out by a written decision of the head of the customs authority or the person who replaces it, if there are sufficient reasons to believe that the citizen conceals contraband or goods that are direct objects of violation of customs rules or prohibited for import to Ukraine, export from Ukraine or transit through the territory of Ukraine. The personal inspection states only that: "A personal inspection may be conducted by a person authorized to have the same sex with the person being examined and in the presence of two persons of the same sex." Empirical evidence confirms that, in practice, the requirement for the presence of witnesses is often violated, which is a consequence of the weak legal construction of obsolete Soviet law such as the Code of Administrative Offenses, as well as violations by the law enforcer.

Depending on the procedural order, the following basic procedures for examination of the person are distinguished: 1) superficial inspection; 2) personal inspection; 3) personal search / person search. These procedures are clearly regulated by applicable law and are not alternative, as they have their own grounds and procedure.

The content of the foreseen in Art. 264 of the CAO is hardly disclosed. The systematic analysis of scientific literature, interpretative dictionaries and legislation makes it possible to determine that personal examination is provided by the law of actions (manipulations) with the 
body of a person, which restrict the right to liberty and privacy and are carried out by visual and tactile examination, which is carried out for the purpose ascertaining the person's involvement in the commission of an administrative offense or obtaining evidence of his / her commission for the proper consideration of this category of cases.

From the point of view of protecting human rights, which is of the highest social value in Ukraine, its review is a direct interference with privacy. If superficial verification can be carried out by law through both visual and tactile examination of the body of a person or his belongings in the course of preventive activity of authorized persons, then examination of a person in the course of administrative proceedings against a person who has committed an offense requires the fixing of an opportunity to be examined in relation to the offender is at least the same procedures that allow for tactile contact. Consequently, the conduct of a personal examination, especially a tactile one, requires the establishment of procedural safeguards for the protection of the dignity of a person in the Administrative Code.

Thus, we consider it inappropriate to conduct a personal inspection at the place of the offense, firstly, to preserve the evidence and ensure the personal safety of authorized persons, the legislator provides for a procedure of superficial examination, and secondly, the status of the detained person is not determined until the appropriate one is drawn up. procedural document - An administrative offense record or other document as appropriate. Therefore, we consider it quite reasonable to attach to the CAO the duty of a person invited by an authorized official to be present during separate proceedings in cases of administrative offenses when it is clearly necessary to obtain evidence. First of all, these are cases where one authorized person considers the materials and another decides.

Conclusion. Freedom of movement is one of the fundamental non-property human rights, the violation of which is possible only in statutory cases. Therefore, all processes related to their restriction and deprivation should be perfect. In particular, in order to harmonize the legislation, it is proposed to give a legislative definition of administrative detention and to enshrine in Art. 263 of the CUAO the concept of the moment of (actual) detention, the beginning of which is considered to be the moment of actual restriction of freedom of movement by psychological influence on the consciousness of the offender's personality (verbal order) or by taking conclusive actions (tactile contact: physical force, handcuffs and other measures provided by the current legislation).

In addition, in our opinion, it is advisable to strengthen the regulatory requirement to conduct a personal examination exclusively in a special room equipped with a separate from outsiders with legal guarantees of the dignity of the person.

\section{References}

1. Кодекс України про адміністративні правопорушення від 07.12.1984. Відомості Верховної Ради Української РСР. 1984. Додаток до № 51. С. 1122.

2. Звід принципів захисту всіх осіб, що піддаються затриманню або ув'язненню в будьякій формі: Резолюція Генеральної Асамблеї ООН 43/173 від 9 грудня 1988 p. URL:https://zakon.rada.gov.ua/laws/show/995_206.

3. Конституція України від 28 червня 1996 року. Відомості Верховної Ради України. 1996. № 30. Ст. 141.

4. Про затвердження Порядку інформування центрів з надання безоплатної вторинної правової допомоги про випадки затримання, адміністративного арешту або застосування запобіжного заходу у вигляді тримання під вартою : постанова Кабінету Міністрів України від 28 грудня 2011 р. № 1363 URL: https://zakon.rada.gov.ua/laws/show/1363-2011-п.

5. Про Національну поліцію : Закон України від 2 липня 2015 року № 580-VIII. Відомості Верховної Ради Украӥни. 2015. № 40-41. Ст.379.

6. Про правовий статус іноземців та осіб без громадянства : Закон України від 22 вересня 2011 р. № 3773-VI. Голос Украӥни. 2011. 25 жовтня. № 199.

7. Інструкція з організації діяльності чергової служби органів (підрозділів) Національної поліції України URL: https://zakon.rada.gov.ua/laws/show/z0750-17/print.

8. Кримінально-процесуальний кодекс України від 13 квітня 2012 р. № 4651-VI URL: http://zakon5.rada.gov.ua/laws/show/4651-17/print1521026505822979.

9. Митний кодекс України Закон України від 13 березня 2012 року № 4495-VI. Вiдомості Верховної Ради України. 2012. № 44-45. № 46-47. № 48. Ст. 552.

10. Галабурда Н.А. Діяльність міліції щодо застосування заходів забезпечення провадження у справах про адміністративні правопорушення : дис. ... канд. юрид. наук : 12.00 .07 / Дніпроп. держ. ун-т внутр. справ. Дніпропетровськ, 2011. 218 с.

11. Кодекс адміністративного судочинства України від 6 липня 2005 року № 2747-IV. Відомості Верховної Ради України. 2005. № 35-37. Ст. 44.

Received to editorial office 04.12.2019 
1. Kodeks Ukrayiny pro administratyvni pravoporushennya [Code of Ukraine on Administrative Offenses] vid 07.12.1984. Vidomosti Verkhovnoyi Rady Ukrayins'koyi RSR. 1984. Dodatok do № 51. S. 1122. [in Ukr.]

2. Zvid pryntsypiv zakhystu vsikh osib, shcho piddayut'sya zatrymannyu abo uv'yaznennyu v bud'-yakiy formi [A set of principles for the protection of all persons subject to detention or imprisonment in any form]: Rezolyutsiya Heneral'noyi Asambleyi OON 43/173 vid 9 hrudnya 1988 r. URL:https://zakon.rada.gov.ua/laws/show/995_206. [in Ukr.]

3. Konstytutsiya Ukrayiny [The Constitution of Ukraine] vid 28 chervnya 1996 roku. Vidomosti Verkhovnoyi Rady Ukrayiny. 1996. № 30. St. 141. [in Ukr.]

4. Pro zatverdzhennya Poryadku informuvannya tsentriv $\mathrm{z}$ nadannya bezoplatnoyi vtorynnoyi pravovoyi dopomohy pro vypadky zatrymannya, administratyvnoho areshtu abo zastosuvannya zapobizhnoho zakhodu u vyhlyadi trymannya pid vartoyu [On approval of the Order of informing the centers for providing secondary secondary legal aid about cases of detention, administrative arrest or application of a preventive measure in the form of detention]: postanova Kabinetu Ministriv Ukrayiny vid 28 hrudnya 2011 r. № 1363 URL: https://zakon.rada.gov.ua/laws/show/1363-2011-p. [in Ukr.]

5. Pro Natsional'nu politsiyu [On the National Police]: Zakon Ukrayiny vid 2 lypnya 2015 roku № 580-VIII. Vidomosti Verkhovnoyi Rady Ukrayiny. 2015. № 40-41. St.379. [in Ukr.]

6. Pro pravovyy status inozemtsiv ta osib bez hromadyanstva [On the legal status of foreigners and stateless persons]: Zakon Ukrayiny vid 22 veresnya 2011 r. № 3773-VI. Holos Ukrayiny. 2011. 25 zhovtnya. № 199. [in Ukr.]

7. Instruktsiya z orhanizatsiyi diyal'nosti cherhovoyi sluzhby orhaniv (pidrozdiliv) Natsional'noyi politsiyi Ukrayiny [Instruction on organization of activity of the regular service of bodies (units) of the National Police of Ukraine] URL: https://zakon.rada.gov.ua/laws/show/z0750-17/print. [in Ukr.]

8. Kryminal'no-protsesual'nyy kodeks Ukrayiny [Criminal Procedural Code of Ukraine] vid 13 kvitnya 2012 r. № 4651-VI URL: http://zakon5.rada.gov.ua/laws/show/4651-17/print1521026505822979. [in Ukr.]

9. Mytnyy kodeks Ukrayiny Zakon Ukrayiny [Customs Code of Ukraine] vid 13 bereznya 2012 roku № 4495-VI. Vidomosti Verkhovnoyi Rady Ukrayiny. 2012. № 44-45. № 46-47. № 48. St. 552. [in Ukr.]

10. Halaburda, N.A. (2011) Diyal'nist' militsiyi shchodo zastosuvannya zakhodiv zabezpechennya provadzhennya u spravakh pro administratyvni pravoporushennya [Militia activities regarding enforcement of administrative offenses]: dys. ... kand. yuryd. nauk : 12.00 .07 / Dniprop. derzh. un-t vnutr. sprav. Dnipropetrovs'k, 218 s. [in Ukr.]

11. Kodeks administratyvnoho sudochynstva Ukrayiny [Code of Administrative Proceding of Ukraine] vid 6 lypnya 2005 roku № 2747-IV. Vidomosti Verkhovnoyi Rady Ukrayiny. 2005. № 35-37. St. 44. [in Ukr.]

\section{Summary}

In Ukraine, there are many administrative and legal tools for law enforcement, protection of citizens' rights and interests, in which the special place is taken by measures of ensuring proceedings in cases of administrative offenses. Their application implements the termination of administrative misconduct, identification of the offender, drawing up a protocol on an administrative offense, ensuring timely and correct consideration of the case, ensuring the enforcement of decisions in cases of administrative offenses, documenting the fact of evidence of his commission. Recently, the legislation has undergone significant changes in relation to the reform of law enforcement and the judiciary. Therefore, the improvement of legislation on these issues will help create the preconditions for the formation of reliable means of protection of human and citizen's rights and freedoms, interests of society and the state, increase the effectiveness of administrative and legal influence. forcement.

Keywords: administrative detention, delivery, inspection, administrative offense, means of en- 